\title{
Studi Karakteristik Air Tanah Daerah Nganjuk Jawa Timur dengan Isotop Alam
}

\section{Characteristics Study of Regional Groundwater East Java Nganjuk with Natural Isotopes}

\author{
Satrio, Bungkus Pratikno dan Paston Sidauruk \\ Pusat Aplikasi Isotop dan Radiasi, BATAN \\ Jl. Lebak Bulus Raya No. 49 Jakarta 12440 \\ E-mail : satrio@batan.go.id \\ Diterima 11-07-2016; Diterima dengan revisi 26-07-2016; Disetujui 12-08-2016
}

\begin{abstract}
ABSTRAK
Telah dilakukan penelitian air tanah di daerah Nganjuk, Jawa Timur Dengan isotop alam ${ }^{14} \mathrm{C},{ }^{18} \mathrm{O}$ dan ${ }^{2}$ H. Penelitian ini dilakukan dengan mengambil sejumlah sampel air tanah yang berasal dari sumur bor milik PDAM Kabupaten Nganjuk di beberapa lokasi untuk kemudian dilakukan analisis konsentrasi isotop alamnya di lab Hidrologi - PAIR BATAN Jakarta. Tujuan penelitian ini adalah untuk mengetahui karakteristik air tanah di daerah Nganjuk berdasarkan konsentrasi isotop alamnya. Berdasarkan hasil analisis isotop alam ${ }^{18} \mathrm{O},{ }^{2} \mathrm{H}$ dan ${ }^{14} \mathrm{C}$ secara umum air tanah PDAM Kabupaten Nganjuk diklasifikasikan menjadi tiga, yaitu grup-1 (PDAM: Trunojoyo, Kutorejo, Godean), air tanah dengan konsentrasi isotop alam $\delta^{18} \mathrm{O}$ dan $\delta^{18} \mathrm{H}$ paling miskin, yaitu antara $-7,60 \%$ hingga $-6,67 \%$ untuk $\delta^{18} \mathrm{O}$ dan $-45,0 \%$ hingga $-44,3 \%$ untuk $\delta^{18} \mathrm{H}$. Air tanah PDAM Godean mengindikasikan oxygen-shifting dan menghasilkan umur air tanah paling tua, yaitu sekitar 5517 tahun BP. Ketiga air tanah ini diperkirakan berasal dari daerah resapan di lereng Gunung Wilis yang terletak di selatan. Grup-2, yaitu air tanah PDAM Rejoso, memiliki konsentrasi isotop alam $\delta^{18} \mathrm{O}$ dan $\delta^{2} \mathrm{H}$ yang lebih kaya dibandingkan air tanah grup-1 yang mengindikasikan letak elevasi daerah resapannya lebih rendah dari grup-1 dan diperkirakan berasal dari lereng Gunung Pandan yang terletak di utara dengan hasil isotop alam ${ }^{14} \mathrm{C}$ berumur lebih muda, yaitu sekitar 411 tahun BP. Grup-3, yaitu air tanah PDAM Gondang dengan karakter sebagai air tanah yang mengalami evaporasi atau interaksi dengan air permukaan dan indikasi ini diperkuat dengan data isotop alam ${ }^{14} \mathrm{C}$ yang berumur Modern.
\end{abstract}

Kata Kunci : studi air tanah, isotop alam, umur air tanah, Nganjuk

\begin{abstract}
It had been done groundwater study in Nganjuk area East Java using environmental isotopes ${ }^{18} \mathrm{O}$, ${ }^{2} \mathrm{H}$ and ${ }^{14} \mathrm{C}$. This study was done by taking several groundwater samples from bor well of PDAM Nganjuk and the analyzed in lab of hydrology PAIR BATAN Jakarta. The purpose of this study was to determine the groundwater characteristics based on environmental isotopes concentration. The results of the environmental analysis of isotopes ${ }^{18} \mathrm{O},{ }^{2} \mathrm{H}$ and ${ }^{14} \mathrm{C}$ showed that generally groundwater PDAM Nganjuk classified into three, namely the group-1 (PDAM: Trunojoyo, Kutorejo, Godean), with the groundwater concentrations of environmental $\delta^{18} \mathrm{O}$ and $\delta^{18} \mathrm{H}$ were most depleted from $-7.60 \%$ oo to $-6.67 \%$ oo for $\delta^{18} \mathrm{O}$ and $-45.0 \%$ to $-44.3 \%$ for $\delta^{18} \mathrm{H}$. Groundwater of PDAM Godean indicated oxygen-shifting fenomena with the groundwater age was oldest, around 5517 years BP. The groundwater recharge of these group was estimated come from the catchment areas on the slopes of Mount Wilis which located in the south. Group2, ie groundwater of PDAM Rejoso, had a environmental isotope concentration $\delta^{18} \mathrm{O}$ and $\delta^{2} \mathrm{H}$ more enrich than the groundwater of group-1, indicating the location of the groundwater recharge was lower elevation than group-1 and estimated come from the slopes of Mount Pandan which located in the north with the result of the groundwater age was younger, around 411 years BP. Group-3, ie groundwater PDAM Gondang had character as groundwater evaporated or interaction with the surface water which the result of groundwater age was Modern.
\end{abstract}

Keywords : groundwater study, environmental isotopes, groundwater age, Nganjuk 


\section{PENDAHULUAN}

Kabupaten Nganjuk merupakan kabupaten yang terletak di jalan arteri nasional jalur tengah provinsi Jawa Timur, merupakan daerah agraris yang berada diantara lereng Gunung Wilis di sebelah selatan dan Gunung Pandan di sebelah utara [1]. Kabupaten ini berbatasan dengan Kabupaten Bojonegoro di utara, Kabupaten Jombang di timur, Kabupaten Kediri dan Kabupaten Ponorogo di selatan, serta Kabupaten Madiun di barat. Nganjuk juga dikenal dengan julukan Kota Angin. Dengan wilayah yang terletak di dataran rendah dan pegunungan, Kabupaten Nganjuk memiliki kondisi dan struktur tanah yang cukup produktif untuk berbagai jenis tanaman, baik tanaman pangan maupun tanaman perkebunan sehingga sangat menunjang pertumbuhan ekonomi dibidang pertanian. Kondisi dan struktur tanah yang produktif ini sekaligus ditunjang adanya sungai Widas yang mengalir sepanjang 69,332 $\mathrm{km}$ dan mengairi daerah seluas 3.236 Ha, dan sungai Brantas yang mampu mengairi sawah seluas $12.705 \mathrm{Ha}$.

Seiring waktu Kabupaten Nganjuk terus berkembang, baik dalam bidang ekonomi pertanian maupun peningkatan jumlah penduduk dan pemukiman. Meningkatnya jumlah penduduk dan berkembangnya Kabupaten Nganjuk, akan meningkatkan kapasitas kebutuhan air bersih. Disamping itu, Kabupaten Nganjuk tidak terlepas dari bencana kekeringan yang terjadi dalam beberapa tahun terakhir ini, sementara kebutuhan terus meningkat. Pada musim kering, biasanya PDAM maupun instansi terkait melakukan droping air bersih sekitar 2000-2500 L di desa yang mengalami daerah mengalami kekeringan [2]. Selama ini PDAM Nganjuk selaku pengelola air bersih menggunakan sistem gravitasi dan pemompaan [3].

Tujuan penelitian ini yaitu untuk menentukan karakteristik dari air tanah yang berasal dari beberapa sumur bor milik PDAM Kabupaten Nganjuk melalui pendekatan isotop alam ${ }^{18} \mathrm{O},{ }^{2} \mathrm{H}$ dan ${ }^{14} \mathrm{C}$. Isotop alam ${ }^{18} \mathrm{O}$ dan ${ }^{2} \mathrm{H}$ merupakan isotop stabil yang banyak digunakan sebagai tracer untuk mengetahui karakteristik dan asal-usul air tanah. Sedangkan isotop alam ${ }^{14} \mathrm{C}$ merupakan isotop radioaktif alam yang banyak digunakan untuk menentukan umur air tanah.

Topografi Kabupaten Nganjuk meliputi, sebelah barat daya merupakan daerah pegunungan (Gunung Wilis) dengan ketinggian 1000 sampai dengan $2300 \mathrm{~m}$ di atas permukaan laut (DPL), potensial untuk tanaman perkebunan dan holtikultura. Bagian tengah merupakan dataran rendah dengan ketinggian 60-140 m DPL, merupakan daerah pertanian tanaman pangan dan holtikultura. Bagian utara merupakan daerah pegunungan (Pegunungan Kendeng) dengan ketinggian 60-300 m DPL, yang merupakan daerah hutan jati, lahan potensial untuk tanaman tembakau dan bahan galian kapur. Sebagian besar kecamatan berada pada dataran rendah dengan ketinggian antara 46 meter sampai dengan 95 meter di atas permukaan laut. Sedangkan 4 (empat) kecamatan berada pada daerah pegunungan dengan ketinggian 150 meter sampai 750 meter di atas permukaan laut. Daerah tertinggi terletak di Desa Ngliman Kecamatan Sawahan. Pada bagian dataran rendah, keadaan air tanah merupakan air tanah dangkal. Kabupaten Nganjuk dilewati oleh Kali Widas yang berasal dari Kabupaten Madiun dan Kali Kuncir yang melewati Kota Nganjuk di bagian utara dan selatan. Kedua sungai tersebut bertemu di Kali Kedungsoko yang mengalir ke utara bertemu dengan Kali Widas. Kali Widas tersebut mengalir ke timur melalui Kecamatan Lengkong dan bermuara di Kali Brantas yang merupakan batas wilayah kabupaten Nganjuk bagian timur [4].

\section{BAHAN DAN METODE}

\section{Lokasi pengambilan sampel}

Pengambilan sampel air tanah dilakukan di beberapa lokasi sumur bor milik PDAM Kabupaten Nganjuk. Terdapat lima lokasi sumur bor yang dipilih dan kelimanya berada diantara Gunung Wilis di selatan dan Gunung Pandan di utara. Tabel 1 berikut memperlihatkan posisi dan elevasi lokasi pengambilan sampel air tanah. Sementara itu peta lokasi pengambilan sampel air tanah tersebut dapat dilihat pada Gambar 1.

\section{Pengambilan sampel untuk analisis isotop ${ }^{18} \mathrm{O}$ dan ${ }^{2} \mathbf{H}$}

Sampel air sebanyak $20 \mathrm{ml}$ dimasukkan kedalam botol khusus kedap udara dengan cara mendekatkan botol terhadap sumber air atau memasukkannya kedalam sumber $[5,6]$.

a. Hindarkan adanya gelembung udara dalam sampel dengan cara memasukkan sample secara pelahan-lahan. 
Tabel 1. Lokasi Pengambilan Sampel Air Tanah PDAM Kabupaten Nganjuk

\begin{tabular}{ccccc}
\hline \multirow{2}{*}{ No. } & \multirow{2}{*}{ Nama Sampel } & \multicolumn{2}{c}{ Koordinat } & \multirow{2}{*}{ Elevasi (m, dpl) } \\
\cline { 3 - 4 } & & X & Y & \\
\hline 1 & PDAM Trunojoyo & $599045.15 \mathrm{mE}$ & $9157894.79 \mathrm{mS}$ & 61 \\
2 & PDAM Godean & $598713.75 \mathrm{mE}$ & $9153419.88 \mathrm{~m} \mathrm{~S}$ & 69 \\
3 & PDAM Gondang & $605786.02 \mathrm{mE}$ & $9167702.90 \mathrm{mS}$ & 63 \\
4 & PDAM Rejoso & $599876.77 \mathrm{mE}$ & $9167889.08 \mathrm{~m} \mathrm{~S}$ & 66 \\
5 & PDAM Kutorejo & $597399.13 \mathrm{mE}$ & $9162694.39 \mathrm{mS}$ & 63 \\
\hline
\end{tabular}

b. Setelah sampel terisi penuh dan tidak ada gelembung udara tutup botol tersebut hingga kedap udara.

\section{Pengambilan sampel untuk analisis ${ }^{14} \mathrm{C}$}

Pengambilan sampel air tanah untuk analisis isotop ${ }^{14} \mathrm{C}$ dilakukan melalui tahapan berikut [7]. a. Sebanyak 60 liter sampel air dimasukan ke dalam tangki penampung dan kedalamnya dituangkan 5 gram $\mathrm{FeSO}_{4}$.

b. Sambil dilakukan pengadukan, tuangkan $40 \mathrm{ml}$ larutan $\mathrm{NaOH}$ sehingga $\mathrm{pH}$ sampel mencapai 12.

c. Sambil terus dilakukan pengadukan, tuangkan $500 \mathrm{ml}$ larutan $\mathrm{BaCl}_{2}$ sehingga akan terbentuk endapan senyawa $\mathrm{BaCO}_{3}$.

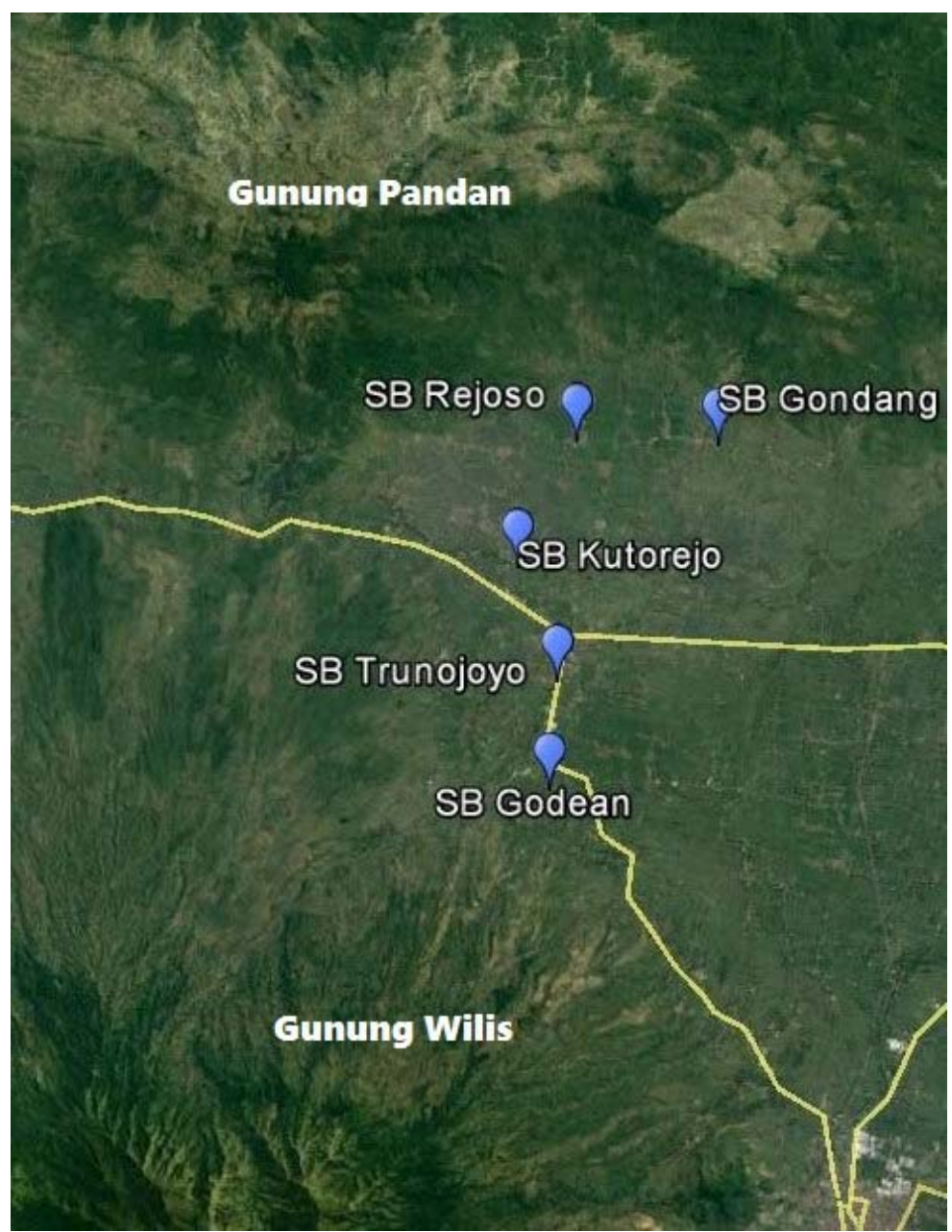

Gambar 1. Peta lokasi pengambilan sampel air tanah PDAM Kabupaten Nganjuk 
d. Agar proses pengendapan lebih cepat, tuangkan $40 \mathrm{ml}$ larutan praestol sambil dilakukan pengadukan.

e. Endapan yang terbentuk dimasukan ke dalam botol plastik 1 liter.

\section{Analisis isotop ${ }^{18} \mathrm{O}$ dan deuterium}

Analisis ${ }^{18} \mathrm{O}$ dan deuterium dilakukan menggunakan alat liquid-water stable isotope analyzer LGR (Los Gatos Research) DLT-100 seperti dapat dilihat pada Gambar 3. Hasil analisis isotop ${ }^{18} \mathrm{O}$ dan ${ }^{2} \mathrm{H}$ dihitung dengan membandingkan terhadap standar internasional SMOW (Standard Mean Ocean Water). Standar ini digunakan sebagai acuan isotop rasio ${ }^{18} \mathrm{O} /{ }^{16} \mathrm{O}$ dan $\mathrm{D} / \mathrm{H}$ yang memiliki nilai 0 (zero). Isotop rasio ${ }^{18} \mathrm{O} /{ }^{16} \mathrm{O}$ dan $\mathrm{D} / \mathrm{H}$ dari sampel relatif terhadap standar dinyatakan dengan notasi $(\delta)$ dalam sataun permill $(\%)$ melalui persamaan berikut $[8,9]$. gelas $21 \mathrm{ml}$. Selanjutnya dilakukan proses pencacahan menggunakan alat Liquid Scintillation Analyzer (LSA) 2910 TR Perkin Elmer. Proses pencacahan dilakukan selama 20 menit dengan 50 kali pengulangan [11].

\section{HASIL DAN PEMBAHASAN}

\section{Hasil analisis isotop alam $\left(\delta^{18} \mathrm{O}\right.$ dan $\left.\delta^{2} \mathrm{H}\right)$}

Tabel 2 memperlihatkan hasil analisis isotop alam $\delta^{18} \mathrm{O}$ dan $\delta^{2} \mathrm{H}$ air tanah milik PDAM Kabupaten Nganjuk. Berdasarkan hasil analisis tersebut terlihat bahwa konsentrasi isotop stabil $\delta^{18} \mathrm{O}$ berkisar antara $-7,60 \%$ oo hingga $-4,74 \%$ oo dan isotop stabil $\delta^{2} \mathrm{H}$ antara $-45,0 \%$ o hingga $-36,4 \%$. Variasi konsentrasi isotop alam $\delta^{18} \mathrm{O}$ dan $\delta^{2} \mathrm{H}$ seperti ditunjukkan Tabel 2 menunjukan karakteristik dan asal-usul dari masing-masing

Tabel 2. Hasil Analisis Isotop Alam $\delta^{18} \mathrm{O}$ dan $\delta^{2} \mathrm{H}$

\begin{tabular}{clcc}
\hline No. & Nama Sampel & \multicolumn{1}{c}{$\delta^{18} \mathrm{O}$} & $\delta^{2} \mathrm{H}$ \\
\hline 1 & PDAM Trunojoyo & $-7,60 \pm 0,25$ & $-45,0 \pm 1,0$ \\
2 & PDAM Godean & $-6,67 \pm 0,21$ & $-44,6 \pm 0,7$ \\
3 & PDAM Gondang & $-4,74 \pm 0,23$ & $-36,4 \pm 1,5$ \\
4 & PDAM Rejoso & $-6,40 \pm 0,14$ & $-39,3 \pm 1,4$ \\
5 & PDAM Kutorejo & $-7,01 \pm 0,34$ & $-44,3 \pm 0,3$ \\
\hline
\end{tabular}

$$
\delta=\frac{R_{\text {Sampel }}-R_{\text {SMOW }}}{R_{\text {SMOW }}}
$$

Dimana, $\quad \delta: \delta^{2} \mathrm{H}$ atau $\delta^{18} \mathrm{O}$

$$
\mathrm{R}={ }^{2} \mathrm{H} /{ }^{1} \mathrm{H} \text { atau }{ }^{18} \mathrm{O} /{ }^{16} \mathrm{H}
$$

\section{Analisis ${ }^{14} \mathrm{C}$}

Sampel karbonat dalam bentuk senyawa $\mathrm{BaCO}_{3}$ atau $\mathrm{CaCO}_{3}$ direaksikan dengan $450 \mathrm{ml}$ larutan asam $\mathrm{HCl} 10 \% \mathrm{ml}$ dalam kondisi vacuum sehingga akan diperoleh gas $\mathrm{CO}_{2}$ melalui persamaan reaksi berikut [10].

$$
\mathrm{BaCO}+2 \mathrm{HCl} \rightarrow \mathrm{BaCl}_{2}+\mathrm{H}_{2} \mathrm{O}+\mathrm{CO}_{2 \mathrm{~L}}
$$

Gas $\mathrm{CO}_{2}$ yang didalamnya mengandung ${ }^{14} \mathrm{CO}_{2}$ kemudian diserap menggunakan larutan Carbosorb/Permafluor sebanyak $30 \mathrm{ml}$ pada alat $\mathrm{CO}_{2}$ absorption line sehingga akan terbentuk larutan Carbamat. Sebanyak $21 \mathrm{ml}$ senyawa Carbamat kemudian dituangkan ke dalam vial sampel air tanah tersebut [12]. Selanjutnya, dengan menggunakan persamaan garis meteorik Indonesia, yaitu $\delta^{2} \mathrm{H}=8 \delta^{2} \mathrm{H}+14 \%$ o [13], semua data isotop alam $\delta^{18} \mathrm{O}$ dan $\delta^{2} \mathrm{H}$ diplotkan dalam bentuk grafik hubungan $\delta^{2} \mathrm{H}$ terhdap $\delta^{18} \mathrm{O}$ sebagaimana dapat dilihat pada Gambar 2.

Berdasarkan grafik hubungan alam $\delta^{2} \mathrm{H}$ terhdap $\delta^{18} \mathrm{O}$ (Gambar 2), secara umum asal-usul air tanah milik PDAM Kabupaten Nganjuk dapat dikelompokan menjadi tiga sebagai berikut:

1. Grup-1. Air tanah grup ini memiliki konsentrasi isotop alam ${ }^{18} \mathrm{O}$ dan ${ }^{2} \mathrm{H}$ paling miskin dibandingkan air tanah grup lainnya dengan konsentrasi $\delta^{18} \mathrm{O}$ antara $-7,60 \%$ hingga $-6,67 \%$ dan $\delta^{18} \mathrm{H}$ antara $-45,0 \%$ hingga $-44,3 \%$ o. Air tanah pada grup ini meliputi PDAM: Trunojoyo, Kutorejo dan Godean. Berdasarkan grafik tersebut terlihat bahwa ketiga air tanah PDAM tersebut diperkirakan berasal dari elevasi daerah resapan yang relatif sama, yaitu dari arah 
lereng Gunung Wilis yang terletak di selatan (elevasi antara 1000 - $2300 \mathrm{~m} \mathrm{dpl}$ ). Air tanah PDAM Trunojoyo dan Kutorejo masih memiliki karakter sebagai air meteorik atau air hujan. Sementara itu, air tanah PDAM Godean mengalami pergeseran dari komposisi asal tanah PDAM Rejoso berasal dari lereng Gunung Pandan yang terletak di utara.

3. Grup-3. Air tanah yang merupakan grup ini yaitu PDAM Gondang. Sebagaimana telah dijelaskan di atas bahwa air tanah PDAM Gondang ini memiliki konsentrasi isotop alam

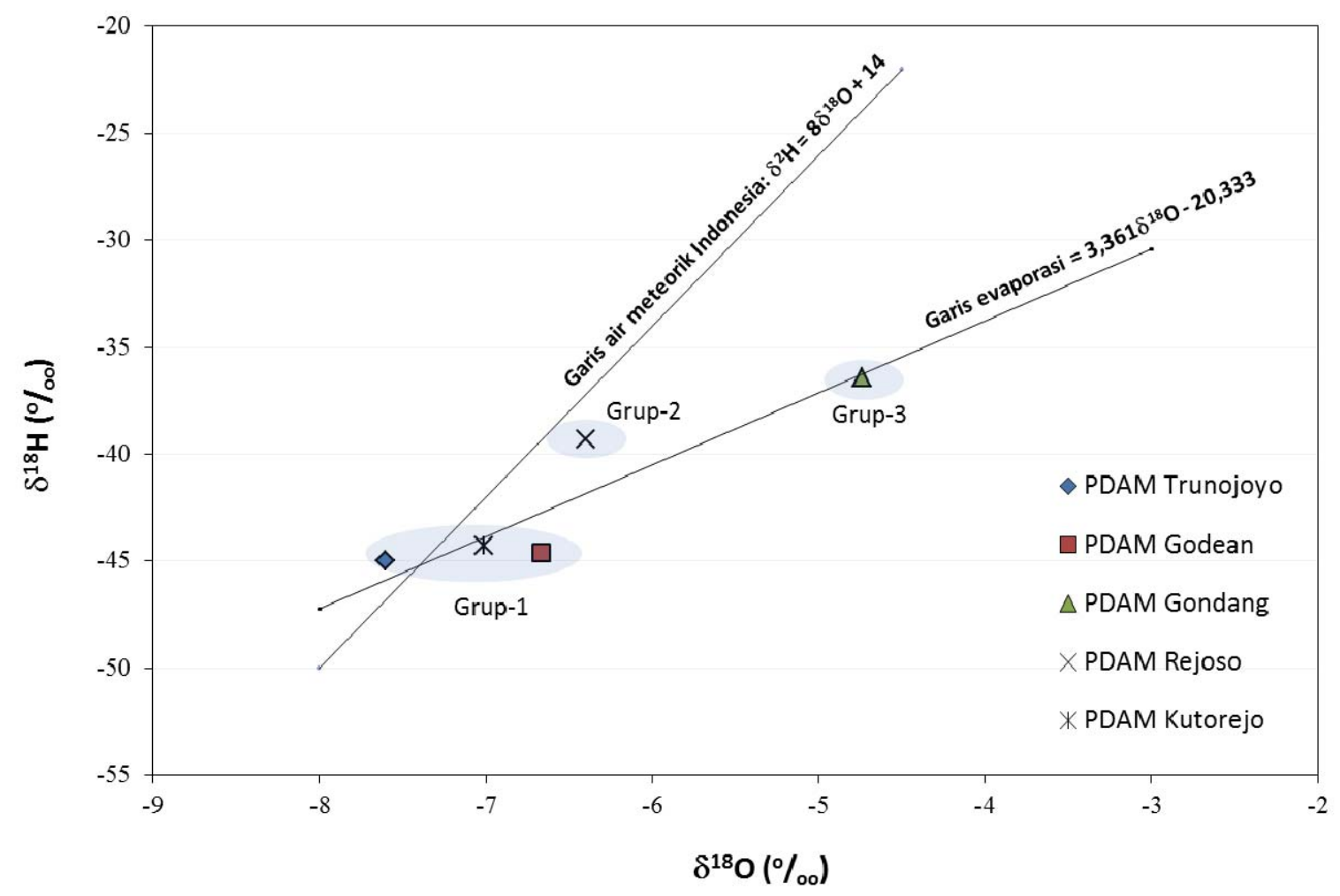

Gambar 2. Grafik hubungan $\delta^{2} \mathrm{H}$ terhadap $\delta^{18} \mathrm{O}$ air tanah PDAM Kabupaten Nganjuk

sebagai akibat interaksi dengan karbonat dari proses pelarutan batuan yang dilaluinya, yaitu proses pertukaran antara oksigen dari air $\left(\mathrm{H}_{2} \mathrm{O}\right)$ dengan oksigen dari karbonat batuan (seperti oksigen dari proses pelarutan $\mathrm{CaCO}_{3}$ ) sehingga menimbulkan peningkatan konsentrasi oksigen atau dikenal sebagai oxygen shifting. Biasanya sampel dengan gejala oxygen shifting memiliki umur air tanah (isotop alam ${ }^{14} \mathrm{C}$ ) yang realtif lebih tua dari air tanah lainnya.

2. Grup-2. Air tanah grup ini adalah PDAM Rejoso yang memiliki konsentrasi isotop alam $\delta^{18} \mathrm{O}$ dan $\delta^{2} \mathrm{H}$ yang lebih kaya dibandingkan air tanah grup-1 di atas. Ini mengindikasikan bahwa elevasi daerah resapan air tanah PDAM Rejoso lebih rendah daripada elevasi daerah resapan air tanah PDAM grup-1. Jika dilihat pada peta lokasi sampling, daerah resapan air $\delta^{18} \mathrm{O}$ dan $\delta^{2} \mathrm{H}$ paling kaya dibandingkan sampel air tanah PDAM lainnya. Posisinya pada grafik berada pada garis evaporasi, ini berarti air tanah tersebut telah mengalami proses evaporasi atau mengalami interaksi dengan air permukaan (air sawah, air rawa, air sungai) yang berada di sekitarnya.

\section{Hasil analisis isotop alam ${ }^{14} \mathrm{C}$}

Tabel 3 memperlihatkan hasil analisis isotop alam ${ }^{14} \mathrm{C}$ atau sering disebut pula sebagai umur air tanah atau groundwater dating. Berdasarkan hasil analisis tersebut terlihat bahwa terdapat variasi umur dari masing-masing sampel air tanah milik PDAM Kabupaten Nganjuk. Air tanah paling muda yaitu PDAM Gondang dengan umur 564 tahun BP (before present=1950) dan yang paling tua yaitu air tanah PDAM Godean 
dengan umur 5937 tahun BP. Pada umumnya air tanah yang memiliki umur muda (dalam kisaran ratusan tahun) lebih rentan terhadap perubahan musim, pada saat musim kemarau panjang air tanahnya relatif cepat habis karena ketergantungan terhadap pasokan air hujan tinggi. Sebaliknya air tanah yang memiliki umur tua pada umumnya relatif tidak terpengaruh adanya perubahan musim, saat musim kemarau panjang pun pasokan air tetap ada dengan syarat daerah resapannya dijaga kelestariannya dengan baik.

Menurut Geyh, 2000 air tanah yang keluar di suatu tempat (discharge) tidak mencerminkan 100 percent Modern Carbon (pMC) sebagaimana (catchment geology) seperti dapat dillihat pada Tabel 4 di bawah ini [14].

Daerah Kabupaten Nganjuk merupakan daerah vulkanik, sehingga untuk mengoreksi hasil umur (corrected age) diambil aktivitas awal antara 90 - 100 pMC. Jika diambil aktivitas awal sebesar 95 pMC atau ekivalen dengan koreksi umur sebesar 420 tahun, maka diperoleh data umur terkoreksi seperti dapatdilihat pada Tabel 5 berikut.

Dari Tabel 4 tersebut terlihat bahwa air tanah PDAM Gondang menjadi 144 tahun BP. Sesuai konvensi internasional tentang radiocarbon dating, umur sampel di bawah 200 tahun dianggap

Tabel 3. Hasil Analisis Isotop Alam ${ }^{14} \mathrm{C}$

\begin{tabular}{clcc}
\hline No. & Nama Sampel & pMC & Age (tahun BP) \\
\hline 1 & PDAM Trunojoyo & $90,11 \pm 0,70$ & $861 \pm 30$ \\
2 & PDAM Godean & $48,77 \pm 0,40$ & $5937 \pm 50$ \\
3 & PDAM Gondang & $93,41 \pm 0,75$ & $564 \pm 20$ \\
4 & PDAM Rejoso & $90,43 \pm 0,72$ & $831 \pm 30$ \\
5 & PDAM Kutorejo & $70,72 \pm 0,55$ & $2864 \pm 40$ \\
\hline
\end{tabular}

Tabel 4. Koreksi umur air tanah sesuai jenis batuan daerah penelitian

\begin{tabular}{lcc}
\hline \multicolumn{1}{c}{ Catchment Geology } & Initial Activity (pMC) & $\begin{array}{c}\text { Reservoir Age Correction } \\
\text { (tahun BP) }\end{array}$ \\
\hline Batuan vulkanik & $90-100$ & -1000 to zero \\
Batuan sedimen & 85 & -1300 \\
Daerah karst & $55-65$ & -5000 to -3500 \\
\hline
\end{tabular}

Tabel 5. Koreksi umur air tanah PDAM Nganjuk

\begin{tabular}{clc}
\hline No. & \multicolumn{1}{c}{ Nama Sampel } & Corrected Age (tahun BP) \\
\hline 1 & PDAM Trunojoyo & 441 \\
2 & PDAM Godean & 5517 \\
3 & PDAM Gondang & 144 \\
4 & PDAM Rejoso & 411 \\
5 & PDAM Kutorejo & 2444 \\
\hline
\end{tabular}

saat infiltrasi, karena adanya pengaruh dari pelarutan karbonat batuan sepanjang lintasan pada batuan yang dilaluinya. Karbonat terlarut cenderung memberikan umur yang lebih tua dari semestinya. Untuk itu, perlu dilakukan koreksi umur air tanah (corrected age) sesuai dengan jenis batuan yang dominan di daerah penelitian sebagai umur saat ini atau Modern. Air tanah PDAM Gondang berumur Modern ini sesuai dengan data isotop alam ${ }^{18} \mathrm{O}$ dan ${ }^{2} \mathrm{H}$ sebagaimana telah dijelaskan di atas yang menyatakan bahwa air tanah ini berhubungan air permukaan. Dari data isotop alam ${ }^{18} \mathrm{O}$ dan ${ }^{2} \mathrm{H}$ air tanah PDAM Trunojoyo, Kutorejo dan Godean berasal dari 
daerah resapan di Gunung Wilis, namun ketiganya menghasilkan umur air tanah yang berbeda. Perbedaan ini diduga sebagai akibat lintasan batuan yang dilaluinya yang kemungkinan memiliki porositas yang berbeda pula. Air tanah PDAM Godean, sebagaimana dijelaskan diatas dari data isotop alam ${ }^{18} \mathrm{O}$ dan ${ }^{2} \mathrm{H}$ mengalami oxygen shifting dan menghasilkan umur air tanah lebih tua dari air tanah lainnya, yaitu sekitar 5517 tahun BP. Sementara itu, air tanah PDAM Rejoso menghasilkan umur yang relatif muda sekitar 411 tahun dan sesuai data isotop alam ${ }^{18} \mathrm{O}$ dan ${ }^{2} \mathrm{H}$ berasal dari daerah resapan di Gunung Pandan yang memiliki elevasi $\pm 700 \mathrm{~m}$ dpl yang terletak di utara.

\section{KESIMPULAN}

Studi air tanah pada lima sumur bor milik PDAM Kabupaten Nganjuk, dapat diambil kesimpulan bahwa terdapat tiga sumur bor yang diperkirakan berasal dari daerah resapan di lereng gunung Wilis, yaitu air tanah PDAM: Trunojoyo, Kutorejo dan Godean. Air tanah PDAM Trunojoyo dan Kutorejo masih memiliki karakter sebagai air meteorik, sedangkan air tanah PDAM Godean mengalami fenomena oxygen shifting akibat interaksi dengan batuan karbonat. Sementara itu, air tanah PDAM Rejoso, memiliki konsentrasi isotop alam $\delta^{18} \mathrm{O}$ dan $\delta^{2} \mathrm{H}$ yang lebih kaya dibandingkan air tanah grup-1 dan masih memiliki karakter sebagai air meteorik. Daerah resapannya diperkirakan berasal dari lereng Gunung Pandan yang terletak di utara dengan hasil isotop alam ${ }^{14} \mathrm{C}$ berumur relatif muda, yaitu sekitar 411 tahun BP. Air tanah lainnya, yaitu PDAM Gondang mengindikasikan karakter sebagai air tanah yang mengalami evaporasi atau interaksi dengan air permukaan dan indikasi ini diperkuat dengan data isotop alam ${ }^{14} \mathrm{C}$ yang berumur Modern.

\section{UCAPAN TERIMA KASIH}

Penelitian ini dibiayai melalui DIPA tahun 2012. Penulis mengucapkan terimakasih kepada analis isotop alam di lab Hidrologi PAIR BATAN yang telah membantu proses analisis sampel sehingga datanya dapat digunakan dalam penulisan makalah ini.

\section{DAFTAR PUSTAKA}

1. BPS Kabupaten Nganjuk, Kabupaten Nganjuk Dalam Angka, 2015.

2. Aziz, A dan Masduqi, A., Indeks Kekeringan di Kabupaten Nnganjuk, Prosiding Seminar Nasional Manajemen Teknologi XVIII Program Studi MMT-ITS, Surabaya, 2013

3. Prabawa dan Wasis, Peningkatan Kapasitas Air Bersih Dengan Sumur Bor Di Kecamatan Loceret Kabupaten Nganjuk, Thesis Teknik Sipil D4 ITS, 2010.

4. Bapeda Kabupaten Nganjuk, Potensi dan Unggulan Jawa Timur: Kabupaten Nganjuk, 2013.

5. Satrio dan Paston Sidauruk, Studi Daerah Imbuh Sistem Air Sungai Bawah Tanah Gunungkidul _ - Yogyakarta Menggunakan Isotop Stabil $\delta^{18} \mathrm{O}$ dan $\delta^{2} \mathrm{H}$, Jurnal Ilmiah Aplikasi Isotop dan Radiasi, Vol. 12 No. 2, 2015.

6. Satrio, Hendarmawan, M. Spari Dwi Hadian dan E. Ristin Pujiindiyati, Karakteristik Air Tanah Dangkal Kota Semarang Pada Musim Penghujan Berdasarkan Pendekatan Isotop Stabil $\left({ }^{18} \mathrm{O},{ }^{2} \mathrm{H}\right)$ dan Kimia Air, Jurnal Ilmiah Aplikasi Isotop dan Radiasi, Vol. 11 No. 1, 2015.

7. Satrio \& Taufiq, A., Studi Air Tanah Akuifer Dalam Di Cekungan Semarang-Demak Menggunakan Isotop Alam 14C, Prosiding Pertemuan dan Presentasi Penelitian Dasar Ilmu Pengetahuan dan Teknologi Nuklir, Pusat Sains dan Teknologi Akselerator, Yogyakarta, 9 10 Juni 2015.

8. Edirisinghe, E. A. N. V., Pitawala, H. M. T. G. A., Dharmagunawardhane, H. A. and Wijayawardane R. L., Isotopic Variations in Natural Water and Groundwater Recharge Conditions in The Kalaoya Basin, Sri Langka, Ceylon Journal of Science (Physical Sciences) 18, (2014) 09-16. 
9. Meng, Y., Liu, G., and Li, M., Tracing the Sources and Processes of Groundwater in an Alpine Glacierized Region in Southwest China: Evidence from Environmental Isotopes, Water 2015, 7, 2673-2690; doi:10.3390/w7062673.

10. Satrio, Sudi Asal-usul Air Tanah Daerah Sembalun - Rinjani Nusa Tenggara Barat Menggunakan Isotop Alam, Prosiding Pertemuan dan Presentasi Ilmiah - Penelitian Dasar Ilmu Pengetahuan dan Teknologi Nuklir 2014 Pusat Teknologi Akselerator dan Proses Bahan - BATAN Yogyakarta, 10 - 11 Juni 2014.

11. Satrio dan Prasetio, R., Hubungan Konsentrasi $\mathrm{HCO}_{3}{ }^{-}$dan Bobot $\mathrm{C}_{6} \mathrm{H}_{6}$ pada Analisis Isotop Alam ${ }^{14} \mathrm{C}$ serta Kaitannya dengan Pelaksanaan Sampling di Lapangan, Prosiding Pertemuan dan Presentasi Ilmiah Penelitian Dasar Ilmu Pengetahuan dan Teknologi Nuklir 2016 Pusat Sains dan Teknologi Akselerator, BATAN -
Fakultas Matematika dan Ilmu Pengetahuan Alam, UNS Surakarta, 2016.

12. Sappa, G., Barbieri, M., Ergul, S., and Ferranti, F., Hydrogeological Conceptual Model of Groundwater from Carbonate Aquifers Using Environmental Isotopes $\left({ }^{18} \mathrm{O},{ }^{2} \mathrm{H}\right)$ and Chemical Tracers: A Case Study in Southern Latium Region, Central Italy, Journal of Water Resource and Protection, 2012, 4, 695-716.

13. Bungkus, P. dan Satrio, Garis Meterorik Indonesia, Prosiding Seminar Nasional Geologi Untuk Meningkatkan Kesejahteraan Masyarakat, Penerbit Fakultas Teknik Geologi, Vol. 1, No. 1, Universitas Padjadjaran, Bandung, 24 Mei 2014.

14. Geyh, m.A., An Overview of ${ }^{14} \mathrm{C}$ Analysis in The Study of Groundwater, Radiocarbon, Vol. 42, No. 1, 99-114, 2000. 